\title{
Promoting Social Cohesion: The Development of E- Learning Management System Materials Through Life Based Learning for Sociology of Religion Course
}

\author{
https://doi.org/10.3991/ijet.v15i07.13339 \\ Ahmad Arif Widianto ${ }^{(凶)}$, Joan Hesti Gita Purwasih, Luhung Achmad Perguna \\ Universitas Negeri Malang, Malang, Indonesia \\ ahmad.arif.fis@um.ac.id
}

\begin{abstract}
The development of information and communication technology (ICT) encourages learning transformation to maximize it. Some transformations are through the development of E-Learning Management System (E-LMS). This paper explained the development of E-LMS material which is integrated with Life Based Learning in sociology of religion course. It integrated with life-based learning model through the ADDIE method which consists of Analysis, Design, Development, Implementation and Evaluation. The material was developed by a student group in the form of videos and thematic learning modules based local wisdom. The results of validation and evaluation showed the development can improve the effectiveness and interaction of learning through asynchronous learning in E-LMS. The developed material can improve students understanding of the religious practices and local wisdom of the community. Through life-based learning, students can construct knowledge and make it happen in the learning media produced. In the other hands, the media product that has been produced and validated can be one of the products can be applied in the process of sociology of religion.
\end{abstract}

Keywords-Learning Management System, Life Based Learning, Sociology of Religion Course

\section{Introduction}

Indonesia currently faces the challenges of intolerance and religious radicalism that threaten the life of the nation and state. Various acts of violence, persecution and exclusion of religious groups, especially minorities are rampant in various regions in Indonesia. These actions undermined the inter-religious social cohesion that had been built in the umbrella of Bhinneka Tunggal Ika (unity in diversity). The cause of this condition is social distance and lack of understanding of interfaith teachings. This condition is exacerbated by truth claims forced by certain religious groups over other groups which lead to cases of violence and terrorism.

For example, acts of intolerance and terrorism which are often carried out by certain hardline Islamic groups then form negative stereotypes that Muslims are identical with 
violence. The stereotype then converged on the views of Islamophobia, fears and excessive worries towards Muslims, which undermined social tolerance-based social cohesion.

The weakening of religious tolerance further strengthens the urgency of building social cohesion considering (1) social cohesion is important in realizing social justice, democracy and sustainable development; (2) social cohesion becomes a fundamental instrument to ensure full community participation and cooperation in the process of democracy and sustainable development. Basically every community is vulnerable to conflict caused by disparities in the distribution of welfare, ethnic and cultural diversity and different environmental contexts [1]. Based on Durkheim's view, social cohesion is a community order built by interdependent relationships between community members, loyalty and solidarity[2], [3]. The loss of social cohesion can cause a crisis in society. Therefore, social cohesion must be bound (bonding) to maintain social stability.

This reality becomes important to be realized by the young generation today. As agents of future change, the younger generation must be able to address this reality and contribute to society. Therefore, the subject of Religious Sociology is present to accommodate this goal through lectures that encourage awareness of tolerance-based social cohesion among religious people.

The purpose of developing this Sociology of Religion course departs from BergerSchmitt's [4] thinking, namely through the development of social cohesion in two dimensions. First, trying to reduce disparity, inequality, and social exclusion in society includes regional disparities, equal opportunities and social exclusion. Second, to strengthen the social capital of the community which includes the existence of social relations, involvement in socio-political activities, the quality of social relations, and the quality and institutional community.

To achieve this goal, students need to understand and identify various forms of social cohesion in society. For example, through religious practices and tolerance of people with different socio-cultural characteristics. This can only be accepted by students if they really feel the diversity and religious practices of the community. Therefore, researchers as lecturers in the course of Religion Sociology develop lecture models that are adopted from the Life Based Learning approach.

Research on the implementation and development of BBK is still a little done in Indonesia. For example, Subekti writes about developing information literacy through life-based learning integrated STEM (Science, Technology, Engineering, and Mathematics) [5]. Through the life-based learning approach prospective educators are directed to be able to learn closer to real life. These skills are needed by prospective educators for the life of the 21 st century. Meanwhile, the renewal of this research lies in the application of BBK carried out within the scope of universities and social science studies such as the Sociology of Religion. Especially in discussing the themes of pluralism, religious tolerance, religion and local culture, and the challenges of religious life in social life. Students who take this course are directed to be actively involved in interfaith society as part of life-based learning (LBL).

The result, researchers can show the realization of the LBL learning model in the subject of Religious Sociology. In addition, students can learn the reality of religious 
life and contribute through the work they produce. In the end, this research can provide criticism as well as refinement of the application of LBL which was developed in the lectures on Sociology of Religion.

\subsection{Theoretical framework}

Life based learning comes from several learning resources that open opportunities to develop individual abilities. Life based learning includes the need for a greater balance between creativity and standardization, innovation and uniformity, controls and systems that regulate open individuals. Life based learning focuses on learning from all one's life in every second of time and the source of learning itself [5].

Life based learning recognizes that individuals have knowledge, skills and abilities that are not always seen or recognized by organizations even though they can significantly contribute to the life of the organization. Life based learning also believes that what we experience and learn outside the work environment is important.

Life based learning that emphasizes the practical activities of students in the community [6], [7]. Students are expected not only to get theoretical knowledge, but also to be able to think critically and participate in providing solutions to the problems of intolerance in religious practices of the community.

\section{$2 \quad$ Method}

The development of live based learning uses the ADDIE model (Analyze, Design, Development, Implementation, and Evaluation). The procedures applied in this study adapted the following concept [8].

Table 1. The Purpose of the ADDIE Concept

\begin{tabular}{|c|l|l|}
\hline No. & \multicolumn{1}{|c|}{ Stage } & \multicolumn{1}{c|}{ Goals } \\
\hline 1 & Analyze & Identify the probable causes for a performance gap \\
\hline 2 & Design & Verify the desired performances and appropriate \\
\hline 3 & Develop & Generate and validate the learning resources \\
\hline 4 & Implement & Prepare the learning environment and engage the students \\
\hline 5 & Evaluate & $\begin{array}{l}\text { Assess the quality of the instructional products and processes, both be- } \\
\text { fore and after implementation }\end{array}$ \\
\hline
\end{tabular}

Depending on the concept, the technical implementation of the development of this research was carried out as follows.

\subsection{Analyze}

At this stage the researcher identifies the achievement of competencies, student characteristics which include knowledge, skills and attitudes, and material presentation that is in accordance with the demands of competence. 


\subsection{Design}

The developer pays attention to the following development guidelines:

1) Who and what learning objectives to target

2) What desired competencies through this development

3) What learning strategies are effective and efficient are used

4) How the evaluation and evaluation taken in development learning.

\subsection{Development}

At this stage the developer carries out material collection and the making of learning media based on the references in the previous stage.

\subsection{Implementation}

Developers apply development results to find out their effects on learning that includes aspects of effectiveness, efficiency and attractiveness. The developer also pays attention to aspects of development training for students, equipment and equipment needed, a series of collaborative learning processes, observations of processes and results of development.

\subsection{Evaluate}

At this stage the developer measures the results of the successful development of learning. The criteria that need to be considered in the assessment are students' awareness of the learning process, knowledge or competencies, attitudes or behavior of students, teamwork in learning and the results of the entire series of innovation developments in the form of learning videos.

\section{$3 \quad$ Result and Discussion}

\subsection{Implementation of lived based learning to sociology of religion course}

The design of lectures on life-based learning lasts for one semester or in sixteen meetings. The lecturers and collaborator lecturers reflect together on the achievements of lectures, constraints, the development of the social conditions of the community, and the potential of students who take courses in the Sociology of Religion. Through this process the lecture design is obtained as follows:

1) Theoretical understanding: Discussion, critical review of journal, book.

2) Live based learning: Inter-faith dialogue, social analysis, development of media learning material. 
3) Evaluation: Discussing on threat, weakness in learning practice, mapping of intolerance problem, making problem solving.

4) Reflection: Constructing collective understanding.

5) Social praxis: Inter-faith collaborative action

At the first meeting the lecturer describes the lecture contract and apperception regarding the objectives of the lecture to be achieved. At this meeting interactive discussions were conducted with students to obtain input regarding the lecture process that they would carry out [9]. Students also have the opportunity to design the learning process that they will do in one semester [10]. At the second meeting until the fifth meeting the lecture activities enter the theoretical understanding phase[10]. This meeting discussed a lot about the concepts and theories of the sociology of religion. In addition, students were also invited to conduct studies on tolerance, social capital-based social cohesion, pluralism, democracy, human rights, socio-religious conflict, and radicalism. Students are asked to raise these topics through review of journals and books in groups to be presented and discussed together in class[11].

At the sixth meeting students were invited to dialogue to try to explore the phenomena of religious practices around Malang City. They conduct searches through news and pre-surveys on several regions that have social conditions of high religious pluralism. As a result, three interesting locations to be studied were the following locations.

1) Jedong Village, Wagir District, Malang Regency - This village was chosen because of religious diversity, living side by side, never conflict, majority of Islam. Support each other (Hindus support the establishment of the Church), help each other in religious celebrations alternately. From this learning, students are expected to learn social cohesion (harmonism, social capital), religious harmony, a sense of belonging, reciprocal relationships and cultural celebrations together.

2) Gunung Kawi, Wonosari District, Malang Regency - Plural and tolerant society. There are 5 different religious places of worship (mosques, churches, monasteries, Klentheng, Pura). Ethnic Javanese and Chinese live side by side. Has one same sacral place. The same magical belief (Eyang Imam Sudjono). Students can learn firsthand the practice of life of religious tolerance and understand the relation between local wisdom and religion in society. Students are also actively involved in the social process of the celebration of the 1st Suro holiday which is a cross-religious holiday. The existence of the Gunung Kawi pesarean religious tourism and keratin gunung Kawi.

3) Wirotaman Village, Ampel Gading District, Malang Regency - Diversity Village, FKUB Forum, Islam, Christianity, Hinduism, Kejawen, no conflict. Reconciliation is done culturally. There is support from the government. Conflict and reconciliation. Local-based reconciliation. There is a shared responsibility in maintaining the title of village diversity from the government. State relations and commonality in society. 
4) Pacet Mojokerto - This area was chosen because of the presence of local political constellations, the rise of local cultural movements, the resistance of certain religious leaders.

Students and lecturers design the implementation of field activities. They were asked to conduct dialogue and make documentary films to reveal the reality of social, cultural and religious practices in each location[12]. Therefore, at this meeting students need to make and finalize the technical data collection while in the field[13]. This design was carried out for two weeks, namely as the implementation of lectures at the seventh and eighth meetings.

While in the field students are asked to report on field developments regularly. During the field data collection process the lecturers also provide assistance so that they can get direction and solutions when facing obstacles[14]. During this process students can gain experience, understanding, and feel the real reality of the diversity and religious practices of the community. In addition, students also learn to build social attitudes when they have to interact with the community as well as group cooperation while in the field.

At the ninth meeting and ten students made and perfected the existing video into a documentary film. Students and lecturers discuss the findings while in the field and design the video presentation flow. In this process students show their creative ideas in presenting a social reality. The skills and mastery of technology in making a documentary are no stranger to students because they are a generation that is close to technology. Nevertheless, joint evaluations and improvements continue to be made as part of learning. This process is also a space for students to express and show their skills. At the eleventh, twelve and thirteenth meetings video screenings of the work of each group were conducted. This activity is accompanied by discussion activities so that each group can analyze the relevance of the theory of religious sociology to the practice of religious tolerance and intolerance. In the end they can build awareness of the importance of tolerance and social cohesion in religious life. At the meeting of the fourteen lecturers, they invited students to reflect on the lecture they had carried out. The discussion took place to find out their perceptions and views regarding the usefulness of LBL. In addition, at the end of the session the lecturer distributes instruments to students through random sampling. This is part of the process of measuring the success of the application of LBL both qualitatively and quantitatively. Meanwhile, in the fifteenth and sixteenth meetings lectures were filled with final semester examinations.

\subsection{The result of lived based learning implementation in sociology of religion course}

The results of the application of LBL model lectures can be divided into four categories: usefulness, material understanding, media, and effectiveness. As for each description the explanation of these aspects the researcher presents as follows.

The average questionnaire shows that students feel the application of LBL during lectures is very useful. Meanwhile, qualitatively students stated that they had new ex- 
periences in the field. Through this experience students feel that they can easily understand and apply sociological theory to the social realities of society. It is this experience that guides them closer to the community so that they are able to develop alternative recommendations to build a new social and more contextual [15].

In terms of understanding the material the average states well. Meanwhile, qualitatively students state that learning becomes easier to understand. As students who are still sitting in the third semester, they consider the sociological theories studied now not to be theoretical and abstract but grounded. They can also criticize and refine existing theories even though the context of the problems observed is relatively micro social. This condition shows that the learning process occurs when they work, not learning to work as stated by Staron [5].

The media they present in the classroom through videos is considered very interesting. This condition is indicated by their opinion stating that videos can effectively help understand the material. Audio visual display is considered more fun because it does not cause boredom. Of course, the process of presenting the video is accompanied by inter-group discussions so that information exchanges and thought processes occur. Through this interactive learning based technology and digital environment, the students able to making collaborative action [16].

According to them, video media is also very suitable with the characteristics of their current generation. The process of making media provides an opportunity for them to channel talent and expression. In the end, the media they create can provide other benefits, such as channels for voicing the strengthening of social cohesion and teaching practices in schools.

Students feel the LBL lecture process that has been applied is very effective. This condition is indicated by the opinion of students who feel that they are required to continue to think critically during lectures [6]. First, they feel challenged when they have to observe, identify, and map the conditions of socio-religious diversity in the community. Both students can try to document and visualize it in videos that are easy to understand [17]. The third practice is solving various problems in the field through the art of leadership and management of human resources. Through this process students can learn to hone aspects of knowledge, skills and social holistically.

\subsection{The supported and threated aspect in lived based learning on sociology of religion}

Lived Based Learning support elements can be categorized based on internal and external factors. Internal factors originate from within students, namely the enthusiasm to find and try new things. The field project encourages more enthusiasm for learning than it is to be monotonous in class [18]. Meanwhile, external factors originated from the instructor's stimulus to initiate the lecture process that was more fun "out of the class". Students are also facilitated by financial assistance from lecture development projects initiated by lecturers. Therefore, students do not feel burdened by the existence of field fees. They can rent field equipment, meet accommodation, transportation, and other technical needs. 
Even so, the implementation of the LBL lecture also experienced obstacles. For example, students must practice the field between regular lectures in other courses. Therefore, the chosen location can only be done around Malang Regency. Monitoring the implementation of the field also cannot always be accompanied by lecturers considering the location of one another is different. Student field mastery in collecting data and images is not maximal. Their experience is inadequate so cooperation between members is often colored by conflict [5].

\section{Conclusion}

The development of information technology encourages the transformation of innovative and creative learning. This study shows that the development of learning innovations can improve effectiveness, understanding and planting pluralism values in students. The sociological material of religion which has tended to be theoretical and textual so far can be easily understood through life-based learning. This is because students understand directly and practically related to socio-religious issues in the community. Thus, students' understanding becomes more comprehensive which integrates textual and contextual aspects of religious sociology material.

\section{$5 \quad$ References}

[1] N. Strategy, "Council of Europe Action Plan for Social Cohesion, approved by the Committee of Ministers of the Council of Europe on 7 July 2010," Retrieved form: http://www.coe.Int/t/dg3/socialpolicies/socialcohesiondev/source/2010Strategy_ActionPlan_SocialCohesion. pdf, 2018.

[2] Y. Berman dan D. Phillips, "Indicators for social cohesion," Paper submitted to the European Network on Indicators of Social Quality of the European Foundation on Social Quality, Amsterdam, 2004. https://doi.org/10.1007/978-0-230-36109-6_7

[3] A. Portes dan E. Vickstrom, "Diversity, social capital, and cohesion," Annual review of sociology, vol. 37, hlm. 461-479, 2011. https://doi.org/10.1146/annurev-soc-081309-150022

[4] R. Berger-Schmitt, Social cohesion as an aspect of the quality of societies: Concept and measurement. ZUMA, 2000.

[5] M. Staron, "Life-based learning model-a model for strength-based approaches to capability development and implications for personal development planning," Australian Government Department for Education Science and Training and TAFE NSW Available on-line at: http://learningtobeprofessional.pbworks.com/w/page/32893040/Life\%20based\%20learning Accessed, vol. 21, no. 12, hlm. 2014, 2011.

[6] I. Thomas, "Critical thinking, transformative learning, sustainable education, and problembased learning in universities," Journal of Transformative Education, vol. 7, no. 3, hlm. 245264, 2009. https://doi.org/10.1177/1541344610385753

[7] B. Kurniawan, I. Idris, A. Purnomo, A. Wiradimadja, dan S. Sukamto, "Using Broadcasting Learning Design to Enhance Student's Experiential Skill," Int. J. Emerg. Technol. Learn., vol. 14, no. 16, hlm. 172-180, Agu 2019. https://doi.org/10.3991/ijet.v14i16.10652

[8] R. M. Branch, Instructional design: The ADDIE approach, vol. 722. Springer Science \& Business Media, 2009. 
[9] D. E. Alvermann, C. E. Hynd, dan G. Qian, "Effects of interactive discussion and text type on learning counterintuitive science concepts," The Journal of Educational Research, vol. 88, no. 3, hlm. 146-154, 1995. https://doi.org/10.1080/00220671.1995.9941293

[10] B. O. Omatseye, "THE DISCUSSION TEACHING METHOD: AN INTERACTIVE STRATEGY IN TERTIARY LEARNING.," Education, vol. 128, no. 1, 2007.

[11] W. J. Tikunoff, "Interactive Research and Development on Teaching. Final Report.," 1979.

[12] C. S. Suchar, "Grounding visual sociology research in shooting scripts," Qualitative sociology, vol. 20, no. 1, hlm. 33-55, 1997.

[13] H. C. Harton, D. S. Richardson, R. E. Barreras, M. J. Rockloff, dan B. Latané, "Focused interactive learning: A tool for active class discussion," Teaching of Psychology, vol. 29, no. 1, hlm. 10-15, 2002. https://doi.org/10.1207/s15328023top2901 03

[14] M. Glazer, "Field work in a hostile environment: a chapter in the sociology of social research in Chile," Comparative Education Review, vol. 10, no. 2, hlm. 367-376, 1966. https://doi.org/10.1086/445227

[15] E. Tartari, A. Tartari, dan D. Beshiri, "The Involvement of Students in Social Network Sites Affects Their Learning," International Journal of Emerging Technologies in Learning (iJET), vol. 14, no. 13, hlm. 33-46, 2019. https://doi.org/10.3991/ijet.v14i13.10453

[16] W. D. Sulistyo dan U. N. Idris, “The Development of E-PAS Based on Massive Open Online Courses (MOOC) on Local History Materials.," International Journal of Emerging Technologies in Learning, vol. 14, no. 9, 2019. https://doi.org/10.3991/ijet.v14i09.10143

[17] N. Selwyn dan K. Facer, "The sociology of education and digital technology: past, present and future," Oxford Review of Education, vol. 40, no. 4, hlm. 482-496, 2014. https://doi. org/10.1080/03054985.2014.933005

[18] A. Al-Huneidi dan J. Schreurs, "Constructivism based blended learning in higher education," dalam World Summit on Knowledge Society, 2011, hlm. 581-591. https://doi.org/ $\underline{10.1007 / 978-3-642-35879-1 \quad 74}$

\section{Authors}

Ahmad Arif Widianto is one of the lecturers in Sociology department, Faculty of Social Science, Universitas Negeri Malang. He is interested in sociology of religion, local wisdom, and learning innovation.

Joan Hesti Gita Purwasih is a lecturer in Sociology department, Faculty of Social Science, Universitas Negeri Malang. She is majoring in learning media and related information technology in education.

Luhung Achmad Perguna is a lecturer in Sociology department, Faculty of Social Science, Universitas Negeri Malang. He is interested in information technology in education and technological development.

Article submitted 2020-01-22. Resubmitted 2020-02-13. Final acceptance 2020-02-23. Final version published as submitted by the authors. 